\title{
A STUDY OF ARGILLIC HORIZONS IN SOME SOILS IN MOROCCO
}

\section{J.J. REYNDERS}

Department of Soils, State University of Utrecht, Utrecht (The Netherlands)

(Accepted for publication September 9, 1972)

\begin{abstract}
Reynders, J.J., 1972. A study of argillic horizons in some soils in Morocco. Geoderma, 8: 267-279.

Whether some soils observed in Morocco prior to the 1966 conference on Mediterranean soils held in Madrid had argillic horizons was the subject of active discussions. Textural differences between Aand B-horizons were obvious. Consequently, individual horizons of a number of profiles were sampled for micromorphological study. No clay films were observed in thin sections representing the B-horizons free in carbonate. Peds had pressure faces and internal striations in the matrix. Microchurning and swelling and shrinking are believed to have obliterated evidence of clay illuviation in the B-horizons, but clay coatings were observed at greater depth in well-developed $B_{c a}$-horizons.

These observations and processes justify considering the B-horizon as argillic.
\end{abstract}

\section{INTRODUCTION}

The term "Mediterranean soils" denotes a wide range of red and brown coloured soils originally found only in the Mediterranean region with its characteristic climate. At the international conference on Mediterranean soils held at Madrid in 1966 Mancini declared that the soils at issue should be placed in at least five or six of the orders of the U.S.D.A. Soil Classification System (7th Approximation). In the years prior to this conference the FAO-working group on soils divided the Mediterranean soils into red and brown subtypes, both having a well-expressed textural B-horizon. Mancini (1966) suggested elimination of the term "Mediterranean" from soil science. Applying the 7th Approximation system, these soils should be included in the Xeralfs, whereas according to the "Definitions of Soil Units for the Soil Map of the World" the soils were grouped as Luvisols (Dudal, 1968).

During the tour in Morocco examples of Mediterranean soils observed at most stops were classified tentatively according to the U.S.D.A. system (Soil Survey Staff, 1967). The presence or absence of argillic horizons was of major importance to the proper placement of soils in the system. Identification of such horizons, however, could not be made with assurance from the field observations. Consequently, the present study has been made to elucidate this issue. Undisturbed samples were taken from individual horizons of a number of soils. These represented various types in the earlier French classification (Aubert, 1965), but in the present system the soils are grouped in the subclass of "sols fersiallitiques" (Duchaufour, 1970). 
SOILS

The soils selected and their essential profile characteristics are as follows (for details see Appendix I $)^{\star}$ :

(a) Profile No.11. A "sol rouge méditerranéen modal", which was classified as an "Ultic Haploxeralf" in the field (Lepoutre, 1967). The soil has a rather uniform reddishbrown colour, with a silt loam surface layer and a locky to prismatic clayey subsoil. The peds in the subsoil have shiny surfaces.

(b) Profile No.4. A transition between a "sol brun isohumique subtropical modal" and a "sol châtain isohumique subtropical", which was classified as a "Typic to Vertic Haploxeroll" (Massoni and Missante, 1967). The profile has a dark reddish-brown surface layer of silty clay loam texture and a blocky to prismatic clayey subsoil; at greater depth an accumulation of calcium carbonate is found. The entire profile contains free calcium carbonate, increasing in content with depth.

(c) Profile No.7. A "sol châtain isohumique subtropical modal", which was classified as a "Calcic Argixeroll" (Massoni and Missante, 1967). The surface layer of this profile is dark reddish-brown sandy clay loam; the subsoil consists of reddish-brown clay with prismatic structure having shiny ped surfaces, and has a sharp lower boundary with highly calcareous material.

(d) Profile No.18. A "sol rouge méditerranéen lessivé", which was classified as a "Typic Rhodoxeralf" (Billaux, 1967). A dark reddish-brown sandy loam forms the surface layer and the subsoil consists of sandy clay with prismatic structure and shiny ped surfaces.

Limestone is found at some depth in each profile.

Under the present climate all soils have a thermic temperature regime and a xeric moisture regime.

\section{CLASSIFICATION CRITERIA}

Generally, the argillic horizon in the U.S.D.A. classification has to meet the following requirements:

(1) The ratio between amounts of clay in the B- and the A-horizons should be 1.2 or more, with some exceptions. If the A-horizon contains more than $40 \%$ clay the B-horizon must contain at least $8 \%$ more.

(2) Clay skins should be present in the B-horizon, forming at least $1 \%$ of the matrix in thin-sections.

Many soils do not give rise to difficulty in determining these criteria. However, some soils do and a number of them are found in the Mediterranean region. Attention will successively be paid to the influences of textural analysis, surface erosion and clay minerals on these criteria.

The textural analysis of soils in semi-arid regions offers difficulties in a number of

\footnotetext{
${ }^{\star}$ Profile numbers correspond with those in the publications concerned.
} 
cases. Applying routine analyses (pretreatment with hydrochloric acid and sodium pyrophosphate), the complete separation of the finest fractions is not always attained.

A selection of analytical data of some Luvisols from the study of soils in areas with a Mediterranean climate by Bruin (1970) is given in Table I. In more than one aspect there is a discrepancy between the various data of the A-horizons and those of the B-horizons, particularly in the relationship between the percentages of clay, the organic matter, the cation exchange capacities and the clay minerals. In case the sand fraction has a high content of feldspars these minerals may have weathered surfaces, which are comparable to clay skins. As a result the sand in such soils can contribute to a considerable extent in the total C.E.C. found. However, the profiles given in Table I, with the exception of the soil Italy 2 , the sand fractions are composed of a high percentage of quartz with little influence on the total C.E.C.-value.

The considerable differences in clay content between the A- and B-horizons are very poorly reflected in the C.E.C.-values. The possibility of a lithological discontinuity between the horizons is rejected by Bruin, because of the similarity of the light and heavy minerals in the A- and B-horizons.

A rough calculation to approach the C.E.C.-values of the clays themselves gives values which do not agree with the clay minerals detected. It is clear that the most important reason for these discrepancies is that the dispersion of the clay during the analysis was very poor. Generally this effect is stronger in the surface soils than in deeper horizons. In arid soils in Syria experience demonstrated that normal routine analysis can result in less than a quarter of the amount of clay actually found by fully appropriate analysis, e.g. $11 \%$ instead of $45 \%$ clay in the A-horizon. Similar observations have been made by other scientists (e.g., Ruellan, 1970). Routine analysis thus should be used with care in such instances.

However, apart from this, a number of non-recent soils in subtropical and tropical regions shows a distinct increase of clay content with depth without the existence of such a subsurface horizon. The lighter textured topsoil is the result of a lateral transport of clay from the surface layer, a process different from clay leaching within the profile or destruction of clay, or internal weathering. Also Duchaufour (1970) reports an "apprauvrissement" of some surface soils in tropical and subtropical regions. The mobile clay is not found in the B-horizon, but it disappears through "lessivage oblique".

Summarizing it can be said that marked differences in the clay content between A- and B-horizons are not sufficient to prove that the latter are argillic horizons.

Many participants in the tour in Morocco identified clay coatings on ped faces in the B-horizons, which were therefore considered to be argillic horizons. This identification was based primarily on two features. One was a difference in colour between ped interiors and exteriors.

This could be observed when peds were broken, rubbed, or cut. The other was a difference in porosity between ped surfaces and interiors. If a ped surface was less porous than the interior, the surface was believed to be a clay film. If clay coatings are present, ped surfaces are commonly less porous and there may also be differences in colour between 


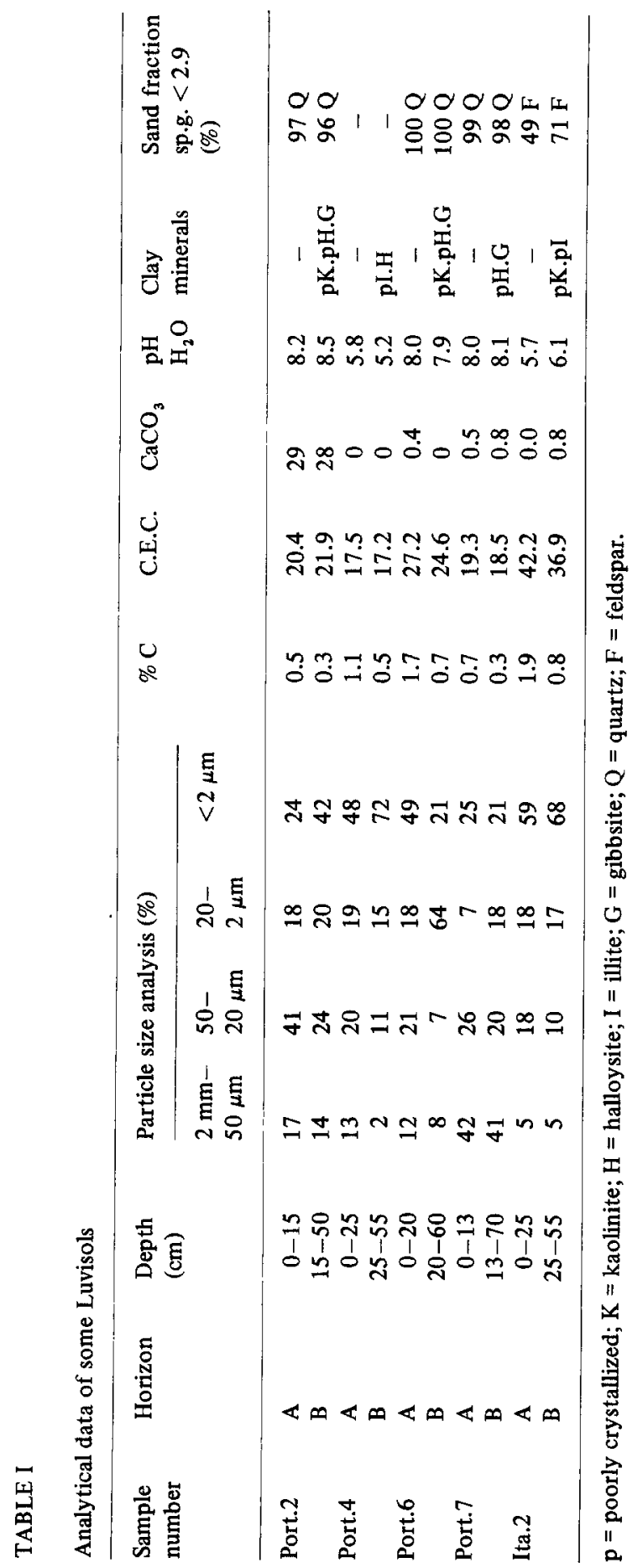


exteriors and interiors. In many heavy-textured B-horizons coatings are obscure or lacking.

Positive identification of clay films is possible only through microscopic examination of thin sections. No clay coatings were found by means of such examination of thin sections from B-horizons of the profiles concerned. This is indicated in the micromorphological descriptions in Appendix II. Both shiny and dull ped surfaces were identified in thin sections as pressure faces or stress cutans. Nettleton et al. (1969) report a similar experience with B-horizons of a Mohave soil in the U.S.A.

The dominant clay minerals in the profiles selected are expanding 2:1 lattice clays such as montmorillonite and interstratified montmorillonite-illite. In the 7th Approximation (1967) it is stated that in such material clay skins are difficult or impossible to identify. Pressure may destroy any clay skin or as a result of wetting the coating material may disintegrate (see also Fedoroff, 1968, and Jongerius, 1970). In that case a marked difference in clay content between eluvial and illuvial horizons accompanied by bare sand or silt grains in the overlying horizon is used as an evidence of an argillic horizon, if there is not a lithological discontinuity between these horizons.

Even in typical Vertisols an increase in the clay content with depth can be observed. Very thin clay coatings, less than $1 \%$ of the section, can be found in some such soils at a depth between $100 \mathrm{~cm}$ and $150 \mathrm{~cm}$. At a shallower depth, in the zone of maximum churning, clay skins have not been found. They have been deformed or destroyed and disappeared as a result of that process (Buursink, 1971).

\section{FURTHER DISCUSSION OF THE MICROMORPHOLOGICAL OBSERVATIONS}

A striking phenomenon in the micromorphological study of the various profiles is that the fabrics of the B-horizons show great similarities. The more or less skelmavosepic fabrics found in every profile reflect a dynamism of swelling and shrinking of the soil. These fabrics indicate that very fine tertiary peds have been formed, built up of elements which initially have been divided by voids. Further, that as a result of pressure and consequent micro-churning within the matrix the elements produce a masepic and skelsepic fabric (see Fig.1). The orientation of clay occurs around sand and silt grains (skeleton grains) as well as around the smallest units of the matrix.

Similar observations have been made by Nettleton et al. (1969). They proved in experiments that clay orientation was formed around sand grains and on peripheries of cracks by drying soil material rich in swelling clays. As a consequence, at least a part of the orientation of clay, causing skelvosepic fabrics, is not due to illuviation. Further, they established a positive relation between increasing amounts of swelling clays and both the absence of clay skins and the kind of fabric. In the Moroccan soils with B-horizons (generally at a depth greater than $30-40 \mathrm{~cm}$ ) containing 40 to $60 \%$ clay, the same masepic fabrics were observed as in some soils with Mediterranean to arid climates in the southwestern United States (Nettleton et al., 1969).

In many soils in Morocco the various forms of accumulation of calcium carbonate, such as very fine dispersed tuff-like ones, local earthy concentrations or "amas", or harder 

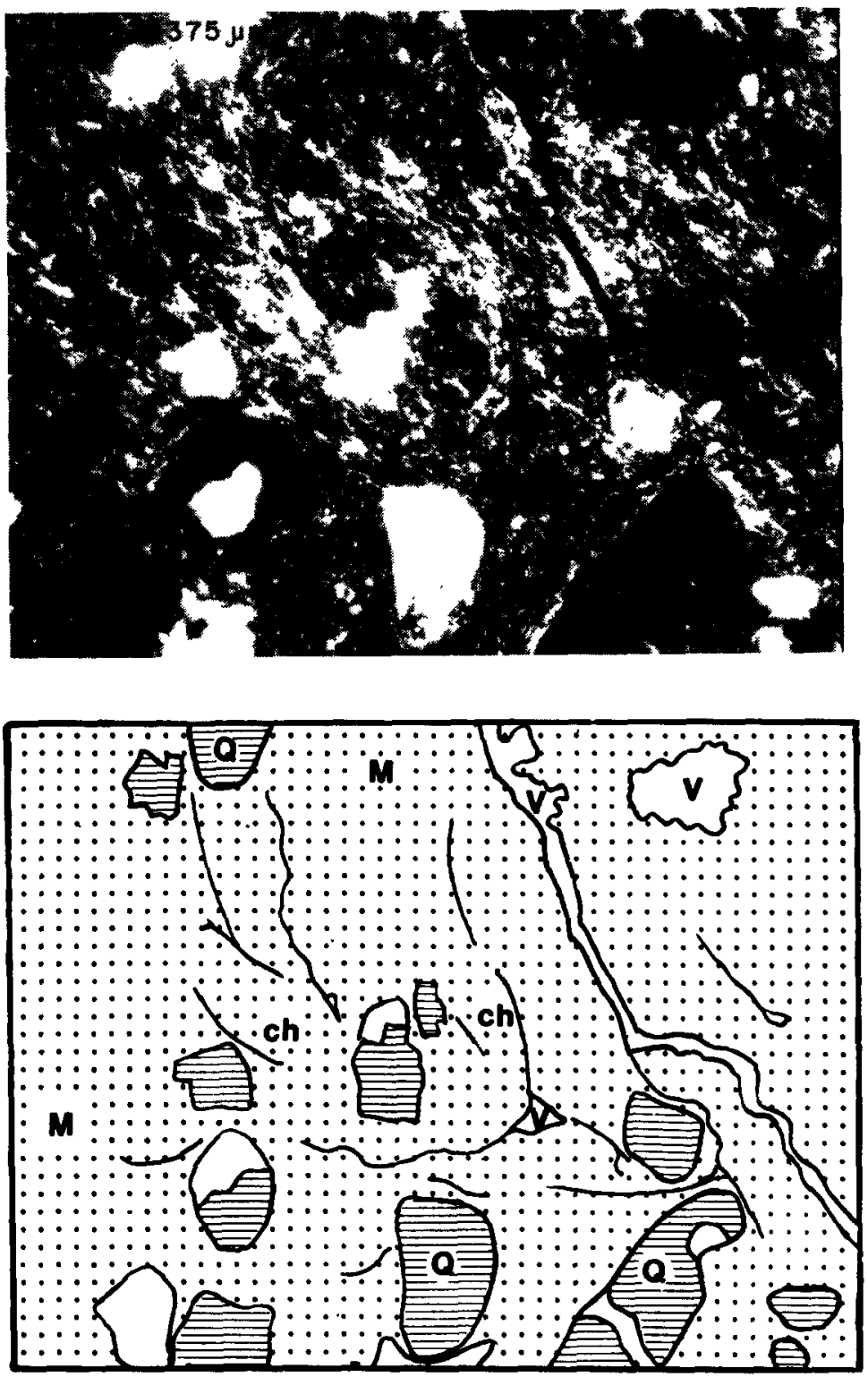

Fig.1. Part of skelmasepic fabric in section of profile No. 18 at $90 \mathrm{~cm}$ depth. $M=$ ferri-argillaceous plasma with phenomena caused by micro-churning ( $c h$ ) in which closed planes (black lines) can be observed; $V=$ voids; $Q=$ quartz. Section under half-crossed nicols.

forms as granules, or even hard pans, are considered to be mainly the result of ancient lateral transport and supply of calcium bicarbonate (Massoni and Missante, 1967; Ruellan, 1970). The infiltration of very diffuse carbonates into the original fabric separates the coarser and finer elements. An exception consists of the scattered very small and transpar- 
ent ferri-argillaceous papules. They remain unaffected by the process of calcification and might be the remnants of a much older genetic process. Other striated patches, stresscutans or parts of the masepic fabrics are not as stable or densely packed as to resist this infusion.

Also Gile et al. (1968) describe the disruptive effect of carbonate engulfment on clay skins in some soils in the State of New Mexico in the United States.

An interesting observation is the presence of argillans in recent voids in material which is no longer subject to expanding or shrinking, namely calcareous nodules or concretions and the calcareous S-matrix (compare micro-morphological descriptions in Appendix II: profile 7 , at $75 \mathrm{~cm}$ depth, and Fig.2). Locally these have been overgrown by carbonate or they have been completely encrusted (see Appendix II: profile 4, $120 \mathrm{~cm}$ depth). This leads to the conclusion that the process of calcification is continuing at present, resulting in redistribution of carbonates and formation of calcium carbonate crystals influenced by wetter periods in the soil (see Appendix II: profile 4, $25 \mathrm{~cm}$ depth). Further lessivage of clay is also a currently active process. No conclusion can be drawn, however, as to its extent. It seems likely that movement of clay takes place into the lower (calcic) horizons on some scale. This was observed in the Mollisols mentioned, viz. the profiles 4 and 7 (Appendix II).

Finally, as a consequence of erosion of many Mediterranean soils, the present Ahorizons have been developed in former B-horizons.

The surface soil became lower in clay content because of surface erosion and lessivage. Traces or patches of the original fabric of the B-horizon are still present. This is reflected in the asepic to insepic fabrics, with local masepic parts.

\section{CONCLUSIONS}

The textures of surface horizons of Moroccan soils studied are lighter than those of the deeper horizons. This may be the result of surface erosion and lessivage.

Micromorphological studies indicate that lessivage of clay occurs into the deeper, highly calcareous B-horizons. In less deep non-calcareous B-horizons greater amounts of expanding clays cause swelling and shrinking. These processes destroy former clay coatings. Clay orientation is also disturbed by accumulation of carbonate.

It is concluded that although the surface soils do not show bare sand and silt grains, the B-horizon should be regarded as an argillic horizon. Similar observations have been reported from the United States.

\section{ACKNOWLEDGEMENT}

Thanks are due to Dr. A. Jongerius, Chief of the Micromorphological Section of the Soil Survey Institute at Wageningen, for the pleasant and critical discussions during the preparation of this paper. 

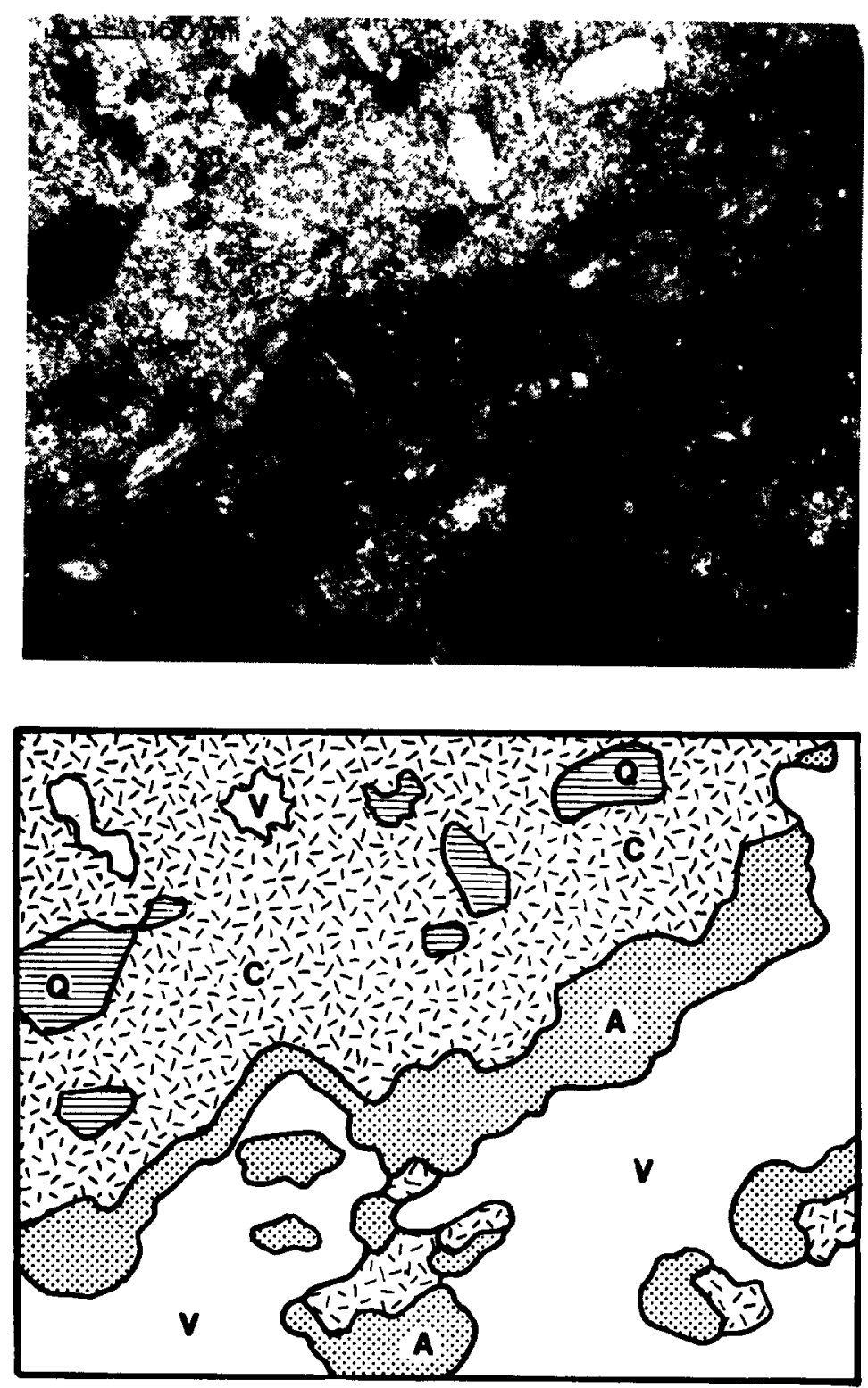

Fig.2. Part of calcareous asepic fabric with ferri-argillan in section profile No.7 at $75 \mathrm{~cm}$ depth. $A=$ argillan; $C=$ silty calcareous materiai; $V=$ voids; $Q=$ quartz. Section under half-crossed nicols. 


\section{APPENDIX I - PROFILE DESCRIPTIONS AND ANALYTICAL DATA}

The profile descriptions give the main soil characteristics. The original French descriptions have been modified by taking into account the field observations made during the excursion. These have been recorded as much as possible according to the system given in the American Soil Survey Manual. The analy tical methods are given in Les Cahiers de la Recherche Agronomique, No.25, I.N.R.A., 1967, Rabat, Morocco.

\section{Profile descriptions}

Profile No.11. Sol rouge méditerranéen modal. Precipitation about $900 \mathrm{~mm}$ per year, elevation $1,450 \mathrm{~m}$.

\begin{tabular}{|c|c|c|}
\hline $0-15 \mathrm{~cm}$ & $\mathbf{A}_{1}$ & $\begin{array}{l}\text { reddish-brown (5YR4/6), silt loam, fine to medium crumby and blocky } \\
\text { structure; hard; sligh tly humic; merging into: }\end{array}$ \\
\hline $15-35 \mathrm{~cm}$ & $B_{21}$ & $\begin{array}{l}\text { reddish-brown ( } 5 \text { YR } 4 / 8 \text { ), clay; medium blocky to subangular blocky structure; } \\
\text { hard; gradually merging into: }\end{array}$ \\
\hline $35-50 / 120 \mathrm{~cm}$ & $\mathrm{~B}_{22}$ & $\begin{array}{l}\text { reddish-brown ( } 5 \text { YR } 4 / 8) \text {, clay; coarse prismatic with medium to coarse blocky } \\
\text { substructure; hard; ped faces smooth and dull to shiny; locally some limestone } \\
\text { blocks; sharp boundary to white limestone, varying in depth between } 50 \text { and } \\
120 \mathrm{~cm} \text {. }\end{array}$ \\
\hline
\end{tabular}

TABLE II

Analytical data profile No.11

\begin{tabular}{|c|c|c|c|c|c|c|c|c|c|}
\hline \multirow{2}{*}{$\begin{array}{l}\text { Depth } \\
\text { (cm) }\end{array}$} & \multicolumn{4}{|c|}{ Particle size analysis (\%) } & \multirow{2}{*}{$\begin{array}{l}\text { O.M. } \\
(\%)\end{array}$} & \multirow[t]{2}{*}{ C.E.C. } & \multirow{2}{*}{$\begin{array}{l}\text { Base } \\
\text { sat. } \\
(\%)\end{array}$} & \multirow{2}{*}{$\begin{array}{l}\mathrm{CaCO}_{3} \\
(\%)\end{array}$} & \multirow[t]{2}{*}{$\mathrm{pH}_{\mathrm{H}_{2} \mathrm{C}}$} \\
\hline & $\begin{array}{l}2 \mathrm{~mm}- \\
50 \mu \mathrm{m}\end{array}$ & $\begin{array}{l}50- \\
20 \mu \mathrm{m}\end{array}$ & $\begin{array}{l}20- \\
2 \mu \mathrm{m}\end{array}$ & $<2 \mu \mathrm{m}$ & & & & & \\
\hline $0-15$ & 24 & 20 & 29 & 11 & 8 & 56.5 & 78 & 0 & 7.3 \\
\hline $15-100$ & 7 & 11 & 25 & 53 & 1.7 & 45.6 & 74 & 0 & 7.8 \\
\hline 120 & 3 & 6 & 29 & 46 & - & 54.8 & 96 & 0 & 8.0 \\
\hline
\end{tabular}

In the clay fraction interstratified illite-montmorillonite is dominant, kaolinite and illite subdominant.

Profile No.4. Sol rouge isohumique subtropical, sol châtain isohumique. Precipitation $432 \mathrm{~mm}$ per year, elevation $455 \mathrm{~m}$.
$0-20 \mathrm{~cm}$
$A_{1}$ dark reddish-brown (5YR3/3), silty clay loam; fine to medium subangular to slightly medium platy structure; hard; some scattered small and hard calcareous concretions; slightly wavy and abrupt boundary;
$20-40 \mathrm{~cm} \quad B_{21 \mathrm{ca}}$ dark reddish-brown (5YR3/3), clay; coarse blocky to prismatic structure with platy substructure; hard; slightly calcareous concretions; gradual boundary;
$40-100 \mathrm{~cm}$
$\mathrm{B}_{22 \mathrm{Ca}}$ reddish-brown (2.5YR4/4), clay; rather compact, fine subangular blocky structure; hard; many hard calcareous concretions, some earthy calcareous accumulations and locally some pseudomycelia; slightly wavy clear boundary;
$100-$ and deeper
$\mathrm{B}_{23 \mathrm{Ca}}$ reddish-brown (2.5YR4/4), clay; subangular blocky structure; hard; calcareous concretions and earthy accumulations. 


\section{TABLE III}

Analy tical data profile No.4

\begin{tabular}{|c|c|c|c|c|c|c|c|c|c|}
\hline \multirow{2}{*}{$\begin{array}{l}\text { Depth } \\
\text { (cm) }\end{array}$} & \multicolumn{4}{|c|}{ Particle size analysis $(\%)$} & \multirow{2}{*}{$\begin{array}{l}\text { O.M. } \\
(\%)\end{array}$} & \multirow[t]{2}{*}{ C.E.C. } & \multirow{2}{*}{$\begin{array}{l}\text { Base } \\
\text { sat. } \\
(\%)\end{array}$} & \multirow{2}{*}{$\begin{array}{l}\mathrm{CaCO}_{3} \\
(\%)\end{array}$} & \multirow[t]{2}{*}{$\mathrm{pH}_{\mathrm{H}_{2}} \mathrm{C}$} \\
\hline & $\begin{array}{l}2 \mathrm{~mm}- \\
50 \mu \mathrm{m}\end{array}$ & $\begin{array}{l}50- \\
20 \mu \mathrm{m}\end{array}$ & $\begin{array}{l}20- \\
2 \mu \mathrm{m}\end{array}$ & $<2 \mu \mathrm{m}$ & & & & & \\
\hline $0-10$ & 20 & 14 & 24 & 39 & 2.0 & 28.8 & 99 & 3.4 & 8.3 \\
\hline $30-50$ & 17 & 10 & 13 & 47 & 1.5 & 24.5 & 98 & 13 & 8.5 \\
\hline $75-100$ & 14 & 7 & 7 & 35 & - & - & - & 37 & 8.6 \\
\hline $100-125$ & 12 & 7 & 8 & 39 & 0.2 & 20.5 & 100 & 35 & 8.7 \\
\hline
\end{tabular}

Over $0-50 \mathrm{~cm}$ depth no change of $\mathrm{SiO}_{2} / \mathrm{Al}_{2} \mathrm{O}_{3}$-ratio, which is 3.2 , of the fine earth. In the clay fractions: montmorillonite dominant, chlorite and interstratified medium, illite and kaolinite weak.

Profile No.7. Sol châtain isohumique. Precipitation $568 \mathrm{~mm}$ per year, elevation $544 \mathrm{~m}$.
$0-15 \mathrm{~cm} \quad A_{1}$
dark reddish-brown (5YR3/2), moist, sandy clay loam; medium blocky to subangular blocky structure; hard; slightly porous; regular straight boundary;
$15-30 \mathrm{~cm}$

$\mathrm{B}_{21}$
very dark reddish-brown (2.5YR2/4), moist, sandy clay loam; medium to coarse blocky to fine to medium prismatic structure; hard; slightly porous, some small and hard calcareous concretions; gradual and slightly wavy boundary;
$3065 \mathrm{~cm}$
$\mathrm{B}_{22}$ dark reddish-brown (2.5YR3/4), moist, clay; medium prismatic structure; hard; slightly porous, shiny, ped faces; some small hard calcareous concretions; distinct boundary;
$65-130 \mathrm{~cm} \quad \mathrm{~B}_{\mathrm{ca}} \quad$ reddish-brown (2.5YR4/6), moist, loamy material; highly calcareous, many small calcareous hard concretions and some earthy calcareous accumulations, amount and density increasing with depth so that general colour becomes whiter; fine to medium subangular blocky structure; hard; slightly porous.

\section{TABLE IV}

Analy tical data profile No.7

\begin{tabular}{|c|c|c|c|c|c|c|c|c|c|}
\hline \multirow{2}{*}{$\begin{array}{l}\text { Depth } \\
(\mathrm{cm})\end{array}$} & \multicolumn{4}{|c|}{ Particle size analysis (\%) } & \multirow{2}{*}{$\begin{array}{l}\text { O.M. } \\
(\%)\end{array}$} & \multirow[t]{2}{*}{ C.E.C. } & \multirow{2}{*}{$\begin{array}{l}\text { Base } \\
\text { sat. } \\
(\%)\end{array}$} & \multirow{2}{*}{$\begin{array}{l}\mathrm{CaCO}_{3} \\
(\%)\end{array}$} & \multirow[t]{2}{*}{$\mathrm{pH}_{\mathrm{H}_{2} \mathrm{C}}$} \\
\hline & $\begin{array}{l}2 \mathrm{~mm}- \\
50 \mu \mathrm{m}\end{array}$ & $\begin{array}{l}50- \\
20 \mu \mathrm{m}\end{array}$ & $\begin{array}{l}20- \\
2 \mu \mathrm{m}\end{array}$ & $<2 \mu \mathrm{m}$ & & & & & \\
\hline $5-15$ & 53 & 14 & 6 & 27 & 1.8 & 19.0 & 100 & 0 & 8.0 \\
\hline $15-30$ & 49 & 10 & 11 & 30 & 1.3 & \pm 25 & 100 & 0 & 8.0 \\
\hline $45-60$ & 38 & 8 & 6 & 48 & 1.1 & - & - & 0 & 8.1 \\
\hline $75-95$ & 14 & 4 & 5 & 26 & 0.4 & 14.0 & 100 & 51 & 8.4 \\
\hline
\end{tabular}

Clay minerals from $0-50 \mathrm{~cm}$ montmorillonite, dominant, interstratified minerals subdominant, illite, chlorite and kaolinite weak. 
Profile No.18. Sol rouge méditerranéen lessivé. Precipitation $574 \mathrm{~mm}$ per year, elevation $580 \mathrm{~m}$.

\begin{tabular}{|c|c|c|}
\hline $0-20 \mathrm{~cm}$ & $A_{1}$ & $\begin{array}{l}\text { dark reddish-brown ( } 2.5 \mathrm{YR} 3 / 4) \text {, sandy loam; slightly humic; rather compact } \\
\text { and crumby; friable, porous; few roots; gradual boundary; }\end{array}$ \\
\hline $20-40 \mathrm{~cm}$ & $\mathrm{~B}_{1}$ & $\begin{array}{l}\text { in }(2.5 \text { YR } 3 / 4) \text {, sandy clay; massive, friable to medium hard } \\
\text { ous; gradual boundary: }\end{array}$ \\
\hline $40-90 \mathrm{~cm}$ & $\mathrm{~B}$ & $\begin{array}{l}\text { reddish-brown ( } 2.5 \mathrm{YR} 3 / 6) \text {, sandy clay; coarse prismatic structure, with } \\
\text { medium subangular substructure; smooth dull and shiny ped surfaces; gradual } \\
\text { boundary; }\end{array}$ \\
\hline $\begin{array}{l}90 \text { and } \\
\text { deeper }\end{array}$ & P & $\begin{array}{l}\text { similar to above layer, but with fine to medium blocky structure; sharp } \\
\text { boundary to yellowish limestone, varying in depth between } 40 \mathrm{~cm} \text { and } 3 \mathrm{~m} \text {. }\end{array}$ \\
\hline
\end{tabular}

TABLE V

Analy tical data profile No.18

\begin{tabular}{|c|c|c|c|c|c|c|c|c|c|}
\hline \multirow{2}{*}{$\begin{array}{l}\text { Depth } \\
\text { (cm) }\end{array}$} & \multicolumn{4}{|c|}{ Particle size analysis (\%) } & \multirow{2}{*}{$\begin{array}{l}\text { O.M. } \\
(\%)\end{array}$} & \multirow[t]{2}{*}{ C.E.C. } & \multirow{2}{*}{$\begin{array}{l}\text { Base } \\
\text { sat. } \\
(\%)\end{array}$} & \multirow{2}{*}{$\begin{array}{l}\mathrm{CaCO}_{3} \\
(\%)\end{array}$} & \multirow{2}{*}{$\mathrm{pH}_{\mathrm{H}_{2} \mathrm{O}}$} \\
\hline & $\begin{array}{l}2 \mathrm{~mm}- \\
50 \mu \mathrm{m}\end{array}$ & $\begin{array}{l}50- \\
20 \mu \mathrm{m}\end{array}$ & $\begin{array}{l}20- \\
2 \mu \mathrm{m}\end{array}$ & $<2 \mu \mathrm{m}$ & & & & & \\
\hline $0-10$ & 78 & 4 & 6 & 12 & 1.8 & 8.0 & 100 & 0 & 7.7 \\
\hline $25-40$ & 57 & 3 & 3 & 37 & 0.9 & 13.5 & 100 & 0 & 7.6 \\
\hline $50-65$ & 45 & 1 & 3 & 51 & 0.6 & 17.5 & 100 & 0 & 7.7 \\
\hline $90-100$ & 37 & 3 & 4 & 56 & 0.7 & 25.0 & 100 & 0 & 7.7 \\
\hline
\end{tabular}

Clay minerals in the layer 50-65 cm: montmorillonite dominant, illite, chlorite and kaolinite subdominant.

The colours in the descriptions are given in the moist status, though the material at the time of the excursion was mainly dry.

\section{APPENDIX II - MICROMORPHOLOGICAL OBSERVATIONS IN THE SECTIONS AVAILABLE ${ }^{\star}$}

Profile No.11 depth $60 \mathrm{~cm}$ : a rather dense S-matrix consisting of reddish (2.5YR) ferri-argillaceous plasma and 5-10\% silt grains; insepic plasmic fabric with transitions to skelvomasepic; a rather parallel pattern of joint-planes between which locally craze-planes; few small ferri-argillaceous papules.

Profile No.4 depth $10 \mathrm{~cm}$ : the S-matrix consists of dark reddish-brown (2.5YR) ferri-argillaceous plasma and about $25 \%$ fine silt-sized grains; asepic with locally some skelsepic and masepic parts; compound packing voids, some wider vughs which are mostly interconnected and many fine vughs; carbonate nodules of silt and some of sand size, in some vughs ferri-argillans and a few ferri-argillaceous papules.

Profile No.4 depth $25 \mathrm{~cm}$ : the S-matrix consists of dark reddish-brown (2.5YR) ferri-argillaceous plasma and about $10 \%$ fine silt-sized grains; throughout the plasma a diffuse but irregular infusion of very fine intercalary calcite crystals; partly weakly insepic, at some places asepic or weakly developed vomasepic; many vughs of different size often interconnected, some channels; some carbonate nodules of silt and sand size; in some vughs pseudomycelium consisting of needle-shaped calcium carbonate crystals; some vughs calcitans; a few ferri-argillaceous papules.

\footnotetext{
${ }^{\star}$ Terminology after Brewer, 1964.
} 
Profile No.4 depth $70 \mathrm{~cm}$ : the S-matrix consists of a slightly reddish-brown (5YR) ferric calcareous-argillaceous plasma and about $5-7 \%$ of silt-sized mineral grains; asepic; locally very weakly developed masepic; some narrow smoothed skew-planes and some channels; about $25 \%$ of the section consists of silt and sand sized nodules partly whitish, partly grey-yellowish; some plane calcitans, and void calcitans within the nodules; a few ferri-argillaceous papules.

Profile No.4 depth $120 \mathrm{~cm}$ : the S-matrix consists of predominantly calcareous plasma, varying in colour from whitish to yellowish-brown, and silt sized mineral grains (about $5 \%$ in the yellowish parts and about $1 \%$ in the whitish parts); asepic and undulic; skew planes and craze planes; locally ped and plane calcitans and compound void argillocalcitans; some argillans embedded in the S-matrix; a few homogeneous transparent ferri-argillaceous papules.

Profile No.7 depth $5 \mathrm{~cm}$ : the S-matrix consists of dark reddish-brown (2.5YR) ferri-argillaceous plasma; about $20 \%$ silt sized grains and about $15 \%$ sand sized grains; skelinsepic and locally masepic; compound packing voids, many mostly interconnected vughs, channels and locally some chambers.

Profile No.7 depth $25 \mathrm{~cm}$ : the S-matrix consists of reddish (2.5YR) ferri-argillaceous plasma; about $15 \%$ of silt sized and $5 \%$ of sand sized grains; skelmavosepic plasmic fabric; a coarse pattern of narrow parallel joint-planes between which narrow smoothed skewplanes (these form more or less micro-peds), locally some vughs and channels; a few channels calcitans, partly intergrading to calcitic crystal tubes; few small homogeneous transparent ferri-argillaceous papules.

Profile No.7 depth $75 \mathrm{~cm}$ (Fig.2): the S-matrix consists of a pale-brown to whitish calcareous silt-sized and about $10 \%$ of sand-sized and also $10 \%$ of silt-sized grains, undulic plasmic fabric; voids intergrading between skew and craze planes; many plane ferriargillans which vary greatly in thickness; plane calcitans which partly cover the ferriargillans.

Profile No.18 depth $10 \mathrm{~cm}$ : the groundmass consists mainly of single skeleton grains and small argillaceous grains; partly also bigger islands of material which is richer in plasma. The last mentioned parts have an insepic fabric, locally skelsepic; the argillaceous grains are locally skelsepic; the silt and sand sized fractions comprise together about $40 \%$ of the section; a few reddish-brown ferri-argillaceous papules.

Profile No.18 depth $50 \mathrm{~cm}$ : the S-matrix consists of red (10R) ferri-argillaceous plasma and about $20 \%$ silt and sand sized mineral grains; skelmavosepic; skew planes and some channels; very few small ferri-argillaceous papules.

Profile No.18 depth $90 \mathrm{~cm}$ (Fig.1): the S-matrix consists of red (10R) ferri-argillaceous plasma, and about $20 \%$ silt and sand sized mineral grains; skelmavosepic; rather parallel joint planes, between which are fine craze planes; ped stress-cutans; very small ferriargillaceous papules.

Profile No.18 depth $180 \mathrm{~cm}$ : the S-matrix consists of red (2.5YR) ferri-argillaceous plasma and about $40 \%$ silt and sand mineral grains; skelmavosepic; a fine network of craze planes and (within the peds) some vughs. 


\section{REFERENCES}

Aubert, G., 1965. Classification des sols. Cah. O.R.S.T.O.M. Sér. Pédol., III (3): 269--288.

Billaux, P., 1967. Profils présentés dans le Saîs. Cah. Rech. Agron., I.N.R.A., Rabat, 25: 117-208.

Brewer, R., 1964. Fabric and Mineral Analysis of Soils. Wiley, London, 470 pp.

Bruin, J.H.S., 1970. A correlation study of red and yellow soils in areas with mediterranean climate. World Soil Resour. Rept., F.A.O., Rome, 39: 95 pp.

Buursink, J., 1971. Soils of Central Sudan. Thesis, State University of Utrecht, Utrecht, 248 pp.

Duchaufour, P., 1970. Précis de Pédologie. Masson, Paris, 480 pp.

Dudal, R., 1968. Definitions of soil units for the Soil Map of the World. World Soil Resour. Rept., F.A.O., Rome, $33: 72 \mathrm{pp}$.

Fedoroff, N., 1968. Genèse et morphologie de sols à horizon B textural en France Atlantique. Sci. Sol, 1: $29-64$.

Gile, L.H. and Grossman, R.B., 1968. Morphology of the Argillic horizon in desert soils of southern New Mexico. Soil Sci., 106: 8-15.

Jongerius, A., 1970. Some morphological aspects of regrouping phenomena in Dutch soils. Geoderma, 4: $311-331$.

Lepoutre, B., 1967. Profils présentés dans le Moyen-Atlas. Cah. Rech. Agron., I.N.R.A., Rabat, 25: $73-116$.

Mancini, F., 1966. On the elimination of the term "mediterranean" in soil science. Trans. Conf. Mediterranean Soils, Soc. Espan. Cienc. Suelo, Madrid, 1966, pp.413-416.

Massoni, C.and Missante, G., 1967. Profils de sols présentés dans la plaine de Tadla. Cah. Rech. Agron., I.N.R.A., Rabat, 25: 5-72.

Nettleton, W.D., Flach, K.W. and Brasher, B.R., 1969. Argillic horizons without clay skins. Soil Sci. Soc. Am. Proc., 33: 121-125.

Ruellan, A., 1970. Contribution à la Connaissance des Sols des Régions Méditerranéennes. les Sols à Profil Calcaire Différencié des Plaines de la Basse Moulouya (Maroc oriental). Thèse, Fac. des Sciences, Univ. de Strasbourg, Strasbourg, 482 pp.

Soil Survey Staff, 1967. Supplement to Soil Classification System (7th Approximation). U.S. Dept. of Agriculture, Washington, D.C., 207 pp. 